\title{
Front Matter: Volume 7370
}

, "Front Matter: Volume 7370," Proc. SPIE 7370, Molecular Imaging II, 737001 (23 July 2009); doi: 10.1117/12.837365

SPIE. Event: European Conferences on Biomedical Optics, 2009, Munich, Germany 


\title{
PROGRESS IN BIOMEDICAL OPTICS AND IMAGING
}

Vol. 10, No. 46

\section{Molecular Imaging II}

\author{
Kai Licha \\ Charles P. Lin \\ Editors
}

15 June 2009

Munich, Germany

Sponsored and Published by

Optical Society of America (United States)

SPIE

Cooperating Organisation

German Biophotonics Research Program (Germany)

Cosponsored by

Photonics4Life-European Network of Excellence for Biophotonics

Air Force Office of Scientific Research (United States) 
The papers included in this volume were part of the technical conference cited on the cover and title page. Papers were selected and subject to review by the editors and conference program committee. Some conference presentations may not be available for publication. The papers published in these proceedings reflect the work and thoughts of the authors and are published herein as submitted. The publisher is not responsible for the validity of the information or for any outcomes resulting from reliance thereon.

Please use the following format to cite material from this book:

Author(s), "Title of Paper," in Molecular Imaging II, edited by Kai Licha, Charles P. Lin, Proceedings of SPIE-OSA Biomedical Optics Vol. 7370 (SPIE, Bellingham, WA, 2009) Article CID Number.

ISSN 1605-7422

ISBN 9780819476463

\section{Copublished by}

\section{SPIE}

P.O. Box 10, Bellingham, Washington 98227-0010 USA

Telephone +1 3606763290 (Pacific Time) · Fax +1 3606471445

SPIE.org

and

Optical Society of America

2010 Massachusetts Ave., N.W., Washington, D.C., 20036 USA

Telephone 1 202/223-8130 (Eastern Time) · Fax 1 202/223-1096

http://www.osa.org

Copyright (@) 2009, Society of Photo-Optical Instrumentation Engineers and Optical Society of America.

Copying of material in this book for internal or personal use, or for the internal or personal use of specific clients, beyond the fair use provisions granted by the U.S. Copyright Law is authorized by SPIE subject to payment of copying fees. The Transactional Reporting Service base fee for this volume is $\$ 18.00$ per article (or portion thereof), which should be paid directly to the Copyright Clearance Center (CCC), 222 Rosewood Drive, Danvers, MA 01923. Payment may also be made electronically through CCC Online at copyright.com. Other copying for republication, resale, advertising or promotion, or any form of systematic or multiple reproduction of any material in this book is prohibited except with permission in writing from the publisher. The CCC fee code is $1605-7422 / 09 / \$ 18.00$.

Printed in the United States of America.

Publication of record for individual papers is online in the SPIE Digital Library.

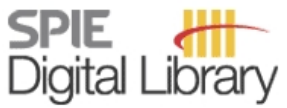

SPIEDigitallibrary.org

Paper Numbering: Proceedings of SPIE-OSA Biomedical Optics follow an e-First publication model, with papers published first online and then in print and on CD-ROM. Papers are published as they are submitted and meet publication criteria. A unique, consistent, permanent citation identifier (CID) number is assigned to each article at the time of the first publication. Utilization of CIDs allows articles to be fully citable as soon they are published online, and connects the same identifier to all online, print, and electronic versions of the publication. In this six-digit CID article numbering system:

- The first four digits correspond to the volume number.

- The last two digits indicate publication order within the volume using a Base 36 numbering system employing both numerals and letters. These two-number sets start with 00, 01, 02, 03, 04, 05, 06, 07, 08, $09,0 A, O B \ldots 0 Z$, followed by $10-1 Z, 20-2 Z$, etc.

The CID number appears on each page of the manuscript. The complete citation is used on the first page, and an abbreviated version on subsequent pages. Numbers in the index correspond to the last two digits of the six-digit CID number. 


\section{Contents}

$\checkmark$ Conference Committee

\section{NOVEL DEVELOPMENTS TOWARD THE CLINICS}

737004 3D reconstruction of spatially resolved fluorescence data: a diagnostics method [7370-14] D. Strat, W. S. L. Strauss, A. Kienle, Univ. Ulm (Germany)

\section{TECHNIQUES FOR LIVE CELL IMAGING}

737007 Improving FRET detection in living cells [7370-15]

C.-W. Chang, M. WU, S. D. Merajver, M.-A. Mycek, Univ. of Michigan, Ann Arbor (United States)

737008 Concepts for optical high content screens of excitable primary isolated cells for molecular imaging [7370-03]

L. Kaestner, S. Ruppenthal, S. Schwarz, A. Scholz, P. Lipp, Univ. des Saarlandes (Germany)

737009 Improving precision in time-gated FLIM for low-light live-cell imaging [7370-09]

C.-W. Chang, M.-A. Mycek, Univ. of Michigan (United States)

\section{NEW PROBES AND CONTRAST MECHANISMS FOR IN VIVO IMAGING}

$7370 \mathrm{OF}$ Image segmentation for biomedical applications based on alternating sequential filtering and watershed transformation [7370-12]

D. Gorpas, D. Yova, National Technical Univ. of Athens (Greece)

7370 OG Dual-modality molecular imaging for small animals using fluorescence and $x$-ray computed tomography [7370-16]

Y. Lin, Univ. of California, Irvine (United States); W. C. Barber, J. S. Iwanczyk, E. Nygard,

N. Malakov, N. E. Hartsough, T. Gandhi, DxRay, Inc. (United States); W. W. Roeck,

O. Nalcioglu, G. Gulsen, Univ. of California, Irvine (United States)

$7370 \mathrm{OH} \quad H y b r i d$ fluorescence tomography/x-ray tomography improves reconstruction quality [7370-11]

R. B. Schulz, A. Ale, A. Sarantopoulos, M. Freyer, R. Söhngen, M. Zientkowska, V. Ntziachristos, Helmholtz Ctr. Munich and Technische Univ. München (Germany) 
Downloaded From: https://www.spiedigitallibrary.org/conference-proceedings-of-spie on 26 Apr 2023

Terms of Use: https://www.spiedigitallibrary.org/terms-of-use 


\title{
Conference Committee
}

\author{
General Chairs
}

Mary-Ann Mycek, University of Michigan (United States)

Wolfgang Drexler, Cardiff University (United Kingdom)

Program Chairs

Christoph K. Hitzenberger, Medizinische Universität Wien (Austria)

Brian W. Pogue, Dartmouth College (United States)

Conference Chairs

Kai Licha, mivenion GmbH (Germany)

Charles P. Lin, Wellman Labs. of Photomedicine, Massachusetts General Hospital (United States)

Program Committee

Samuel Achilefu, Washington University (United States)

Christoph Bremer, University of Munich ULB (Germany)

Giannis Zacharakis, IESL, Foundation for Research and Technology Hellas-FORTH (Greece)

Gang Zheng, Toronto Medical Discovery Tower (Canada)

Session Chairs

1 Novel Developments toward the Clinics

Kai Licha, mivenion GmbH (Germany)

2 Techniques for Live Cell Imaging

Giannis Zacharakis, Foundation for Research and Technology Hellas-FORTH (Greece)

3 New Probes and Contrast Mechanisms for in vivo Imaging

Charles P. Lin, Wellman Labs. of Photomedicine, Massachusetts

General Hospital (United States) 
Downloaded From: https://www.spiedigitallibrary.org/conference-proceedings-of-spie on 26 Apr 2023

Terms of Use: https://www.spiedigitallibrary.org/terms-of-use 